\title{
Italy's contribution to EMBL
}

SIR - As a founder member of the European Molecular Biology Organization (EMBO) and as an active Italian scientist, I wish to supplement what you say on the announced withdrawal of Italy from EMBL (the European Molecular Biology Laboratory, Nature 367, 203 \& 205; 1994).

The idea of creating EMBO originated during an international meeting I organized in Ravello in September 1963. I was then professor of physical chemistry at the University of Naples and director of a CNR unit of the Italian National Centre of Macromolecular Chemistry, whose president was Giulio Natta (who later won a Nobel prize for chemistry). A. Buzzati Traverso had founded in Naples the International Laboratory of Genetics and Biophysics (LIGB) and was an active partner in the foundation of EMBO.

The first step was the legal establishment of EMBO as a private foundation in Geneva, the second the promotion in 1970 through Swiss diplomacy of an intergovernmental structure, the European Molecular Biology Conference (EMBC), with the following aims: (1) to find ways to finance EMBO activities (courses, fellowships, workshops and eventually research grants) and (2) to create an European Molecular Biology Laboratory. An agreement was finally signed in 1973 to build EMBL in Heidelberg (not Nice as originally planned) with the help of the Federal Republic of Germany. EMBL grew quickly under the direction of John Kendrew (another Nobel prizewinner for chemistry).

The main philosophy of EMBO was not the promotion of biology as a specific discipline but of a 'new biology' in Europe, a 'science of science' as defined by J. D. Bernal.

A particular problem of Italian science and technology is the political partition (lottizzazione) of financial resources without regard to scientific excellence or reputation, which may explain the questionable claim of a "quota" in scientific (and not political) international institutions such as EMBO and EMBL. These should operate on the basis of an objective scientific evaluation irrespective of nationality. EMBL has so far achieved its main objectives and is rated among the world's leading laboratories.

It is true that CERN was taken as a model and we had some doubts about EMBL because molecular biology did not need a "big machine". But the moulding of qualified scientists (many of them now professors in Italian universities or directors of research centres) and the facilities provided by the outstations at Hamburg and Grenoble may be taken as just rewards for the financial contribution of
Italy which is based, presumably on some economic parameter. If some think that we spend more than we receive compared with other European countries, we must increase our scientific activities in this field. There is in fact no complaint about CERN. In any case, I think Italy's support for EMBO and EMBL is an "ethical" duty arising from the participation in their foundation of members of the Italian scientific community, as was also the case of CERN.

It is true that some new developing areas of 'new biology' are not properly covered by EMBL (neurobiology, theoretical biology, biomathematics and so on); these areas might be supported by small regional groups or by research grants regulated by EMBO and financed by the European Union.

Finally, I am confident that the international experience and common sense of the present Italian Minister of University and Science will provide a quick solution of the problem.

\section{Alfonso M. Liquori}

Science Faculty,

University of Rome,

TorVergata,

Italy

\section{Descent to tabloid Nature?}

SIR - We note with disgust the latest descent of Nature towards tabloid science. We refer to the "cover story" of Vol. 368, Issue 6468 (17 March 1994) which relates to an article by Perrett et al. on "female attractiveness".

No doubt there is some case for the scientific analysis of human behaviour regarding the influence of appearance on mate selection and reproductive fitness. It is questionable, however, that such a study should be presented as focusing entirely on one sex, and that, as in this case, it should serve to perpetuate a deeply sexist attitude that objectifies women. Further, given that Nature has been a highly regarded international science journal, it must recognize the discreditable impact on research likely to result from emphasizing material of this kind. The public perception of scientific research as a worthwhile enterprise will be severely damaged if this editorial policy is continued.

As a protest, we shall not renew our subscription.

\section{Stephen Jones}

\section{Catherine Jomary}

Rayne Institute,

St Thomas' Hospital,

London SE1 7EH, UK
Delaneyandcancer

SIR - You justifiably say ${ }^{1}$ that "Delaney must go", in reference to the Delaney Clause of the Food Additives Amendment, US Congress, 1958. This clause enacts that "no [food] additive shall be deemed safe if it is found to induce cancer when ingested by man or animals, or if it is found, after tests which are appropriate for evaluation of safety of food additives, to induce cancer in man or animal." The appropriateness of the tests was at the discretion of the Commissioner of Food and Drugs.

Supporters of the clause emphasize that no level of carcinogen is "safe". Of course, it has also become obvious that carcinogens "are present in many, perhaps most foods in a supermarket"

The main obstacle to changing the clause is the one-molecule hypothesis of carcinogenesis. This hypothesis has been repeatedly affirmed by members of the National Cancer Institute (NCI), who have alleged that one molecule of diethylstilboestrol (DES) can induce cancer ${ }^{3}$. Arthur Upton (NCI director 1977-79) said in 1980: "Transformation of a normal cell into a cancer cell could conceivably occur with one molecule of a carcinogen acting on a single cell" 4 .

The "one-molecule hypothesis" sounds scientific, but it is not. If it were valid, we should all be cancerous from the millions of molecules of arsenic, cadmium and chromium in each one of our cells. Hutchinson $^{5}$ has estimated the number of atoms of different elements present in each cell. The number for the heavy metals ranges between $10^{4}$ and $10^{6}$ atoms per cell. The arsenic content of a normal healthy human being is $4.4 \mathrm{mg}$, which is 9 $\times 10^{10}$ molecules of arsenic, a carcinogen, equal to about $10^{5}$ per cell. Dinman 6 pointed out the need to take stochastic considerations into account. He estimated that "a threshold for biological activity exists within a cell at $10^{4}$ atoms": DNA repair mechanisms should also be considered in evaluating the effects of low levels of carcinogens. Also, a molecule of DES would have to compete for acceptor sites with a daily endogenous production per cell of 6,000 molecules of natural oestrogens, which are classified as carcinogens.

A retraction of the clause will have to depend on the perceived invalidity of the one-molecule hypothesis.

\section{Thomas H. Jukes}

Department of Integrative Biology, University of California,

Berkeley, California 94720, USA

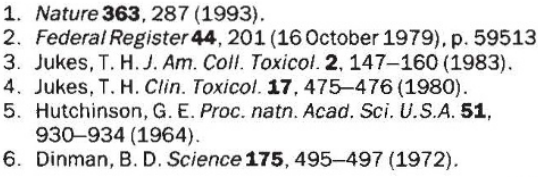

NATURE · VOL 368 • 14 APRIL 1994 